\title{
A comparative phytochemical analysis of cocoa and green tea
}

\author{
R. Subhashini, U.S. Mahadeva Rao, P.Sumathi and Gayathri Gunalan* \\ Dept. of Biochemistry, SRM Arts and Science College, Kattankulathur, Kanchipuram, Tamilnadu, India. \\ ggtarun@yahoo.com*
}

\begin{abstract}
Polyphenols are a large groups of natural compounds widely distributed in variety of plants. They are known to have antioxidant properties with potential health benefits. Green tea and cocoa are the two most widely consumed beverages in the world. Various researches suggest that green tea and cocoa was found to prevent cardiovascular diseases, cancers and kidney stones. The present study is intended to profile the phenols and flavonoids content and to assess the antioxidative capacity in both cocoa and green tea. The results of the study have revealed that one serving of cocoa has higher amount of polyphenols than that of green tea. Hence cocoa froths with antioxidants than green tea and its consumption can improve general health.
\end{abstract}

Keywords: Green tea, cocoa, antioxidants, free radicals, phytochemicals, flavonoids.

Introduction

Medicinal plants are of great importance to the health of individuals and communities. The medicinal value of these plants lies in some chemical substances that produce a definite physiological action on the human body and these chemical substances are called phytochemicals. These are non-nutritive chemicals that have protective or disease preventive property. The most important of these phytochemicals are alkaloids, flavonoids, tannins and phenolic compounds (Hill, 1952). Many of these indigenous plants are used as spices and food plants.

Current research has shown that polyphenols contribute to the prevention of cardiovascular diseases, cancers, osteoporosis and antioxidant character with potential health benefits (Arts \& Hollman, 2005; Lambert et al., 2005; Joseph et al., 2005). They are known to have beneficial effects on cardio vascular system. (Keen et al., 2005; Sies et al., 2005; Vita, 2005) and have a role in the prevention of neurodegenerative diseases and diabetes mellitus (Scalbert et al., 2005).

Tea is an infusion of the leaves of the Camellia sinensis plant and was first discovered in china where it has been consumed for its medicinal properties since 3000 BC (Cheng \& Chen, 1994; Balentine, 1997). It is one of the most widely consumed beverages after water. Green tea is made from more mature tea leaves by withering followed by steaming or firing which inactivates the enzyme to prevent the enzymatic oxidation of catechins. Though mode of consumption of tea differs worldwide, one serving (1cup) of tea beverage is prepared from $2 \mathrm{~g}$ of tea. Green tea leaves (GL) consist of polyphenols, which can make up to $30 \%$ of the fresh leaves by dry weight, but only $10 \%$ by dry weight of black tea. There are three basic polyphenol groups in tea leaves: Catechin, Theaflavins and Thearubigins (Yanishlieva-Maslarowa \& Heinonen, 2001).
Tea catechins can act as antioxidants by donation of a hydrogen atom, as an acceptor of free radicals, interrupting chain oxidation reactions, or by chelating metals (Gramza et al., 2004). It was found that the antioxidant activities of these compounds were higher than those of glutathione, ascorbic acid, and $\alpha$-tocopherol. Recent research papers have reported effects on coronary heart disease in experimental animals by tea or tea catechins. (Tijburg et al., 1997). Tea catechins were responsible for the inhibition of carcinogenesis at all 3 levels (Sakanaka, 1991; Blot et al., 1996; Dreostic et al., 1997; Jankun et al., 1997; Yang, 1997).

Cocoa, was probably first discovered by Europeans on Columbus fourth voyage to the new world in 1502 (Waterhouse et al., 1996; Teissedre et al., 1996). Cocoa is the dried and partially fermented fatty seed of the cacao tree (Theobroma cacao) from which chocolate is made. The polyphenol content of raw cocoa beans differs substantially from that in cocoa powder or chocolate, which are produced by processes involving fermentation, drying and roasting. The flavan-3-ols have been identified as the major antioxidant components of different cocoa ingredients and chocolate preparations (Francene, 2003).

Cacao liquor polyphenols were first described to decrease the expression of interleukin 2 messenger RNA (mRNA) in human lymphocytes in 1997 (Sangboni et al., 1997). Findings with cocoa procyanidins show that flavonoids can modulate cytokines involved in acute inflammatory responses (Sato et al., 1997; Rotondo, 1998). Flavonoid phenolics in chocolate prevent the rancidification of the fat in chocolate, decreasing the need for added preservatives (McGee, 1984).

Since cocoa and green tea has been reported to be rich in phytochemicals, we planned to study the levels of total phenols, flavanoids and oxidant scavenging capacity of both cocoa and green tea and also their.
Research article

CIndian Society for Education and Environment (iSee)
"Antioxidants in cocoa \& green tea" http://www.indjst.org
Subhashini et al. Indian J.Sci.Technol. 
Materials and methods

Commercial cocoa powder was bought from Cadbury's India Pvt. Ltd. Green tea was obtained from Lipton. All other reagents used were of analytical grade.

\section{Sample preparation}

The samples were prepared according to serving size of green tea and cocoa. $7.3 \mathrm{~g}$ ( 2 tables spoonful) of commercial cocoa powder was dissolved in $200 \mathrm{ml}$ of double distilled water at $100^{\circ} \mathrm{C}$. Green tea extract was prepared by infusing $2 \mathrm{~g}$ of green tea in $200 \mathrm{ml}$ of double distilled water at $100^{\circ} \mathrm{C}$ for 2 mins. The samples were then centrifuged in a refrigerated centrifuge at 12000 $\mathrm{g}$ for 5 mins. The resultant

Table 2. Quantitative analysis of total phenols in cocoa and green tea

\begin{tabular}{|l|c|c|}
\hline \multicolumn{1}{|c|}{ Particulars } & $\begin{array}{c}\text { Green Tea } \\
\text { [mg of GAE / } \\
\text { serving] }\end{array}$ & $\begin{array}{c}\text { Cocoa } \\
\text { [mg of GAE / } \\
\text { serving] }\end{array}$ \\
\hline No of Samples, $\mathrm{n}$ & 30 & 30 \\
Mean & 168.8 & 550 \\
Standard & 1.5 & 5.1 \\
Deviation & ${ }^{* * * *}$ & ${ }^{* * * *}$ \\
Students' t test & \multicolumn{2}{|c|}{ GAE - Gallic acid equivalents } \\
${ }^{* * * *} P<0.001$ \\
\hline
\end{tabular}
supernatants were used as final samples for both changes observed. qualitative and quantitative analysis of phytochemicals. Qualitative analyses of phytochemicals were carried out in the aqueous extracts of cocoa and green tea as described by (Trease \& Evans, 1989; Sofowara, 1993).

\section{Estimation of total phenol}

Total Phenol was estimated by the method of folin-ciocalteau. To $0.4 \mathrm{ml}$ of the samples, $9 \mathrm{ml}$ of distilled water was added followed by $1 \mathrm{ml}$ of folin-ciocalteau reagent and shaken well. After incubating for $5 \mathrm{~min}, 10 \mathrm{ml}$ of $7 \%$ sodium carbonate was added to all the flasks. The volume was then made up to $25 \mathrm{ml}$ with distilled water and mixed well. Read the blue color developed at 750 $\mathrm{nm}$ after $90 \mathrm{~min}$ incubation at $23^{\circ} \mathrm{C}$. The amount of total phenol was expressed in milligrams of Gallic acid equivalents (GAE) per serving.

\section{Total flavonoids estimation}

Total flavonoids were estimated by Zhisten method. $1 \mathrm{ml}$ of the sample was taken in different test tubes containing $4 \mathrm{ml}$ of distilled water. At time zero, $0.3 \mathrm{ml}$ of $5 \%$ sodium nitrite was added to all the tubes. At $5^{\text {th }}$ minute, $0.3 \mathrm{ml}$ of $10 \%$ aluminum chloride was added to all the tubes. At $6^{\text {th }}$ minute, $2 \mathrm{ml}$ of $1 \mathrm{M}$ sodium hydroxide were added. The volume in the tubes were immediately diluted with $2.4 \mathrm{ml}$ of distilled water and mixed well. The absorbance of the pink color developed was read at 510 $\mathrm{nm}$ against the blank. The total flavonoids content was expressed in $\mathrm{ml}$ of epicatechin equivalents (ECE) per serving. considered significant.

cocoa and green tea
\begin{tabular}{|l|c|c|}
\hline \multicolumn{1}{|c|}{ Particulars } & $\begin{array}{c}\text { Green tea } \\
\text { [mg of ECE } \\
\text { / serving ] }\end{array}$ & $\begin{array}{c}\text { Cocoa } \\
\text { [mg of ECE } \\
\text { / serving ] }\end{array}$ \\
\hline No of Samples, $\mathrm{n}$ & 30 & 30 \\
Mean & 353 & 566 \\
Standard & 3.2 & 5.2 \\
Deviation & $* * *$ & $* * * *$ \\
Students' t test & Equivalents & \\
\hline \multicolumn{2}{|c|}{ ECE - Epicatechin $-P<0.001$}
\end{tabular}
(Frankel et al., 1993).
Vol. 3 No. 2 (Feb 2010)

ISSN: 0974- 6846

\section{HPLC analysis}

The HPLC analysis of flavanoids and catechins in cocoa and green tea were done by the method of Julie Kowalski (http://www.restek.com/aoi_fff_A006.as p) and Nishitani and Sagesaka (2004) method.

\section{Oxidant scavenging capacity}

Lipid peroxides were determined by the method of Yagi et al. (1978). Conjugated dienes were estimated by the method of Rao and Recknagel (1968).

\section{Statistical significance:}

The values were expressed in mean \pm SD. Statistical analysis was done by students ' $t$ ' test and ' $p$ ' value was arrived at to assess the statistical significance of Values less than 0.02 were

\section{Results and discussion}

Table 1 shows the qualitative analysis of phytochemicals present in green tea and cocoa. Table 2 shows the level of total phenol per serving of green tea and cocoa. The total phenol level was significantly higher $(\mathrm{P}<$ 0.001 ) in cocoa than green tea. Epidemiological studies have shown that consumption of food and beverages rich in phenolic content can reduce the risk of heart disease by slowing the progression of atherosclerosis by acting as antioxidants towards LDL

\section{Fig. 1. Quantitative analysis of cocoa and green tea}

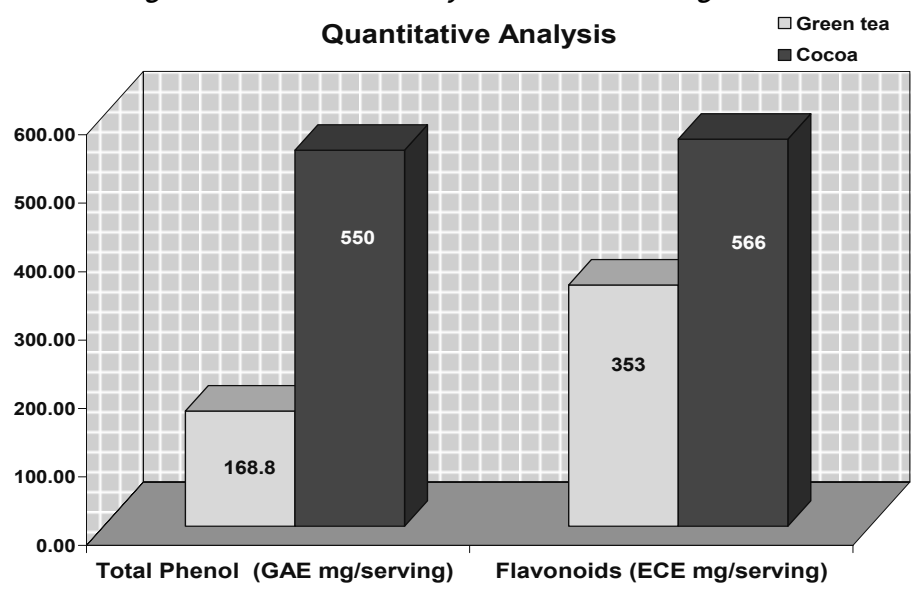

Research article

CIndian Society for Education and Environment (iSee)
"Antioxidants in cocoa \& green tea" http://www.indjst.org
Subhashini et al. Indian J.Sci.Technol. 
The current study has proved that cocoa is a rich source of phenol and it has 2-3 times higher levels of phenol than green tea (Fig.1). Ki Won Lee (2000) has reported higher levels of phenol (GAE) in cocoa than in green tea, corroborating our findings.

Recognition of the health potential of cocoa is a recent development and attention is mainly focused on the possible benefits of cocoa polyphenols as antioxidant. The in vitro protection rendered by the cocoa extracts against LDL per oxidation is due to its phenolic content (Dreosti, 2000). This suggests that cocoa polyphenols may help to protect against the development of coronary heart and cardiovascular diseases. Miller et al. (2006) have reported that cocoa consumption delays oxidation of LDL cholesterol, improves endothelial function, lowers blood pressure and improves platelet function.

Table 4. Quantitative Analysis of different flavonoids in cocoa and green tea by HPLC

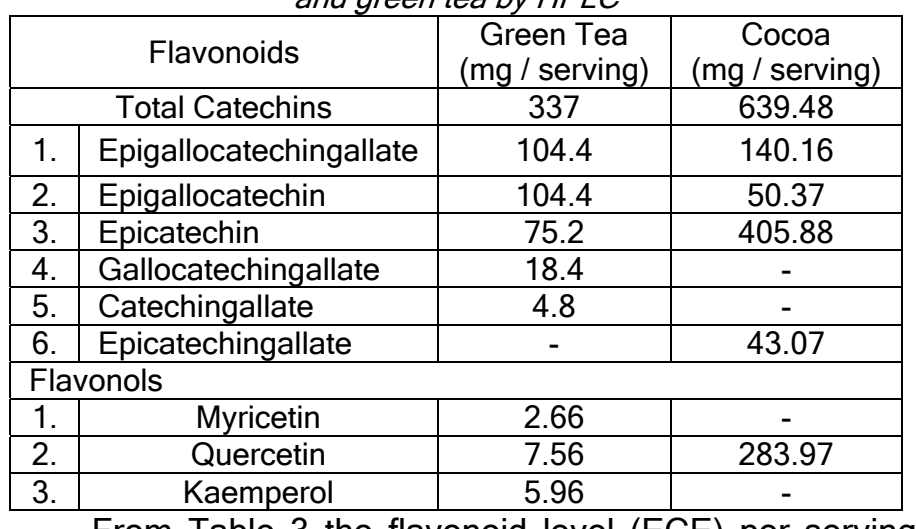

From Table 3 the flavonoid level (ECE) per serving was found to be higher $(P<0.001)$ in cocoa when compared to green tea. Flavonoids are recognized as a very important phytochemical mainly for their antioxidant activity and metal chelating properties. Ki Won Lee et al. (2000) have reported higher levels of flavonoids in cocoa than in green tea. The colorimetric and HPLC analysis of the present investigation confirms the presence of higher levels of flavonoids in cocoa than in green tea.

Dreosti (2000) has reported the beneficial role of flavonoids in variety of cellular processes. Numerous investigators have shown that foods containing phytochemicals with antioxidant potential have strong protective effects against the risk of cancer and cardiovascular diseases (Osman et al., 2004).

The concentration of various flavonoids was estimated by the HPLC analysis and it was shown in the Table.4. It was found that cocoa has catechins namely epigallocatechingallate (EGCG), epigallocatechin, epicatechingallate, epicatechins and flavonol namely quercetin. Green tea was found to contain catechins namely epigallocatechingallate (EGCG), epigallocatechin, epicatechin, gallocatechingallate, catechingallate and flavonols namely myricetin, quercetin and kaemperol. The total amount of flavonoids per serving of cocoa was found to be $923.45 \mathrm{mg}$ which was lower in green tea $(323.38 \mathrm{mg})$. Many researchers have published the similar results (Waterhouse, 1996).

Table 5 shows the levels of LPO and CD in the control liver homogenate and in green tea and cocoa incubated homogenate. It was observed that the level of LPO and CD in cocoa was significantly lesser than $(P<0.001)$ that in green tea incubated homogenate. It reveals that the rate of LPO formation in the liver homogenate was decreased by the presence of cocoa. This sort of antioxidant property might be because of the presence of phytochemicals like phenols and flavonoids. These have redox properties which allow them to act as reducing agents, hydrogen donors, singlet oxygen quenchers and metal chelators. Various researchers have also reported that phenols and flavonoids are potent inhibitors of LDL oxidation (Mcgee, 1984; Hertog, 1993; Tijburg, 1997)

Gallic acid and EGCG, the major antioxidants in tea, have shown strong antioxidant activity but also could act as prooxidants (Shiraki et al., 1994; Johnson \& Loo, $2000)$. Some reports have suggested that a high dose of Gallic acid and EGCG induces cellular DNA damage (Shiraki et al., 1994; Johnson \& Loo, 2000; Szeto \& Benzie, 2002). Long et al. (2000) also showed that the addition of gallic acid and EGCG to commonly used cell culture media led to the generation of substantial amounts of $\mathrm{H}_{2} \mathrm{O}_{2}$, which may cause cellular DNA damage. However, the amount of $\mathrm{H}_{2} \mathrm{O}_{2}$ generated by cocoa rich in procyanidins is such lower than that generated by black and green teas (Long et al., 1999). These results thus indicate that cocoa procyanidins may possess more beneficial effects than green tea phenolics.

In terms of serving size, the intake of phytochemicals is more in cocoa than in green tea. Therefore consumption of cocoa will increase the antioxidative phytochemicals content than green tea.

Table 6 shows the percentage of oxidant scavenging capacity of green tea and cocoa. It was found to be significantly greater in cocoa when compared to green tea. As discussed above this oxidant scavenging capacity

Table 5. Levels of oxidation products in green tea and cocoa incubated liver homogenates

\begin{tabular}{|c|c|c|c|}
\hline Oxidation products & $\begin{array}{c}\text { liver } \\
\text { homogenate } \\
\text { (control) }\end{array}$ & $\begin{array}{c}\text { green tea } \\
\text { + liver } \\
\text { homogenate }\end{array}$ & $\begin{array}{c}\text { cocoa } \\
\text { + liver } \\
\text { homogenate }\end{array}$ \\
\hline $\begin{array}{c}\text { Lipid peroxidation (nmoles of } \\
\text { malondialdehyde/ ml of liver } \\
\text { homogenate) }\end{array}$ & 202 & $62^{\$}$ & $50^{\#}$ \\
\hline $\begin{array}{c}\text { Conjugated dienes (nmoles of } \\
\text { conjugated dienes/ml of liver } \\
\text { homogenate) }\end{array}$ & 70 & $40^{\$}$ & $25^{\#}$ \\
\hline
\end{tabular}

$\$$ - green tea Vs liver homogenate, $P<0.001$ \# - cocoa Vs liver homogenate, $P<0.001$
Research article

Clndian Society for Education and Environment (iSee)
"Antioxidants in cocoa \& green tea" http://www.indjst.org
Subhashini et al. Indian J.Sci.Technol. 
of cocoa might be because of the presence of higher amounts of various antioxidants (phenols and flavonoids) per serving. (Waterhouse et al., 1996) have also demonstrated a $75 \%$ scavenging action per serving of cocoa. These results were similar to that in the present study.

From the above studies it is observed that cocoa has a source of $550 \mathrm{mg}$ of total phenol (GAE) and $566 \mathrm{mg}$ of flavonoids (ECE) and green tea has $168.8 \mathrm{mg}$ of total phenol (GAE) and $353 \mathrm{mg}$ of flavonoids (ECE). Even though green tea has more flavonoids like EGCG and EGC per gram than cocoa, their contribution of phytochemicals to the human diet is less than cocoa. This is because the serving size of cocoa $(7.3 \mathrm{~g})$ is more than green tea $(2 \mathrm{~g})$. From these studies, a conclusion can be drawn that consumption of cocoa can have more beneficial effects with respect to combating diseases like cancer, cardio-vascular diseases and in general boost the immune system.

\section{References}

1. Arts ICW and Hollman PCH (2005) Polyphenols and disease risk in epidemiologic studies. Am. J. Clinical Nutr. 81, 317-325.

2. Blot WJ, Chow WH and McLaughlin JK (1996) Tea and cancer: a review of the epidemiological evidence. Eur. J. Cancer Prevention. 5, 425.

3. Cheng QK and Chen ZM (1994) Tea and Health. Press Chinese Agri. Sci., Beijing, China.

4. Dreosti E (2000) Antioxidant polyphenols in tea, cocoa, and wine. Nutrition. 16, 692-694.

5. Dreosti IE (1997) Cancer biomarkers in the field of tea. Cancer Lett. 1,114.

6. Francene MS, Monica MB and Carl LK (2003) Cocoa and chocolate flavonoids: Implications for cardiovascular health. J. Am. Diet Assoc. 103(2), 215-223.

7. Gramza JK, M Hes and Jedrusek-Golinska (2004) Tea extracts influence on catalytical properties of Fe2+ in lipids. Pol. J. Environ. Studies. 13,143-146.

8. Hertog MGL, Feskens EJM, Hollman PCH, Katan MB and Kromhout D (1993) Dietary antioxidant flavonoids and risk of coronary heart disease: the Zutphen Elderly Study. Lancet. 342, 1007-1011.

9. Hill AF (1952) Economic botany: a textbook of useful plants and plant products. McGarw-Hill Book Company Inc, NY.

10. Jankun J, Selman SH, Swiercz R and SkrzypczakJankun E (1997) Why drinking green tea could prevent cancer. Nature. 387, 561.

11. Johnson M and Loo G (2000) Effects of epigallocatechin gallate and quercetin on oxidative damage to cellular DNA. Mutat. Res. 459, 211-218.

12. Joseph JA, Shukitt-Hale B and Casadesus G (2005) Reversing the deleterious effects of aging on neuronal communication and behavior: beneficial
Vol. 3 No. 2 (Feb 2010)

ISSN: 0974-6846

properties of fruit polyphenolic compounds. Am. J. Clin. Nutr. 81, 313-316.

13. Keen CL, Holt RR, Oteiza PI, Fraga CG and Schmitz HH (2005) Cocoa antioxidants and cardiovascular health.

Am. J. Clin. Nutr. 81, 298-303.

14. Ki Won Lee, Young Jun Kim, Hyong joo Lee and Chang Yong Lee (2003) Cocoa Has More Phenolic Phytochemicals and a Higher Antioxidant Capacity than Teas and Red Wine. J. Agri. Food Chem. 51, 7292-7295.

15. Lambert JD, Hong J, Yang G, Liao J and Yang CS (2005) Inhibition of carcinogenesis by polyphenols: evidence from laboratory investigations. Am. J. Clin. Nutr. 81, 284-291.

16. Long $\mathrm{H}$, Halliwell $\mathrm{B}$, Clement $\mathrm{MV}$ and Ramalingam $\mathrm{J}$ (2000) Hydrogen peroxide: Ubiquitous in cell culture and in vivo. IUBMB Life. 50, 251-257.

17. Long LH, Lan AN, Hsuan FT and Halliwell B (1999) Generation of hydrogen peroxide by "antioxidant" beverages and the effect of milk addition. Is cocoa the best beverage? Free Radical Res. 31(1), 67-71.

18. McGee JH (1984) On food and cooking. Charles Scribner's Sons, NY.

19. Miller KB, Stuart DA, Smith NL, Lee CY, McHale NL, Flanagan JA, Ou B and Hurst WJ (2006) Antioxidant activity and polyphenol and procyanidin contents of selected commercially available cocoa-containing and chocolate products in the United States. J. Agri. Food Chem. 54(11), 4062-4068.

20. Nishitani E and Sagesaka YM (2004) Simultaneous determination of catechins, caffeine and other phenolic compounds in tea using new HPLC method. J. Food. Compos. Anal. 17, 675- 85.

21. Osman H, Nasarudin R and Lee SL (2004) Extracts of cocoa (Theobroma cacao L.) leaves and their antioxidation potential. Food Chem. 86, 41-46.

22. Rao KS and Recknagel RO (1968) Early onset of lipid peroxidation in rat liver after carbon tetrachloride administration. Exp. Mol. Pathol. 9: 271-278.

23. Rotondo S, Rajtar G, Manarini S, Celardo A, Rotillo D, de Gaetano G, Evangelista $V$ and Cerletti C (1998) Effect of trans-reservatrol, a natural polyphenolic compound, on human polymorphonuclear leukocyte function. $\mathrm{Br} . \mathrm{J}$. Pharmocol. 123,1691-1699.

24. Sakanaka, S (1991) Prevention Effects of Tea Polyphenols against Dental Caries. Proc. Int/. Symp. Tea Sci. pp:243-247, $26^{\text {th }}-29^{\text {th }}$ August, Shizuoka, Japan.

25. Sangboni C, Suzuki N and Sakane T (1997) Polyphenols in chocolate, which have antioxidant activity, modulate immune functions in humans in vitro. Cell Immunol. 177, 129-136.

26. Sato M, Miyazaki T, Kambe F, Maeda K and Seo H (1997) Quercetin, a bioflavonoid, inhibits the
Research article

CIndian Society for Education and Environment (iSee)
"Antioxidants in cocoa \& green tea" http://www.indjst.org
Subhashini et al. Indian J.Sci.Technol. 
induction of interleukin 8 and monocyte chemo attractant protein-1 expression by tumor necrosis factor in cultured human synovial cells. J. Rheumatol. 24,1680-1684.

27. Scalbert $A$, Manach $C$, Morand $C$, Rémésy $C$ and Jiménez L (2005) Dietary polyphenols and the prevention of diseases. Critical Rev. Food Sci. Nutr. 45(4), 287-306.

28. Shiraki M, Hara, Y Osawa, T Kumon, H Nakayama, T Kawakishi, S(1994) Antioxidative and antimutagenic effects of theaflavins from black tea. Mutat. Res. 323, 29-34.

29. Sies H, Schewe T, Heiss C and Kelm M (2005) Cocoa polyphenols and inflammatory mediators. Am. J Clin Nutr. 81, 304-312.

30. Sofowara A (1993) Medicinal plants and Traditional medicine in Africa. Spectrum Books Ltd, Ibadan, Nigeria. p. 289.

31. Szeto YT and Benzie IF (2002) Effects of dietary antioxidants on human DNA ex vivo. Free Radical Res. 36(1), 113-118.

32. Teissedre PL, Frankel EN, Waterhouse AL, Peleg H and German JB (1996) Inhibition of in-vitro human LDL oxidation by phenolic antioxidants from grapes and wines. J. Sci. Food Agric. 70: 55-61.

33. Tijburg LBM, Mattern T, Folts JD, Weisgerber UM and Katan MB (1997) Tea Flavonoids and Cardiovascular Diseases: A Review. Critical Rev. Food Sci. Nutr. 37, 771-785.

34. Trease GE and Evans WC (1989) Pharmacognsy. $11^{\text {th }}$ edn. Brailliar Tiridel Can. Macmillian Publ.

35. Vita JA (2005) Polyphenols and cardiovascular disease: effects on endothelial and platelet function. Am. J Clin Nutr. 81, 292-297.

36. Waterhouse AL, Shirley JR and Donovan JL (1996) Antioxidants in chocolate. Lancet. 348-834.

37. Yagi K (1978) Lipid peroxides and human diseases. Chem. Physiol. Lipids. 45, 337-351.

38. Yang CS (1997) Inhibition of carcinogenesis by tea. Nature. 389,134-135.

39. Yanishlieva-Maslarowa NN and Heinonen IM (2001) Sources of natural antioxidants: Vegetables, fruits, herbs, spices and teas. Antioxidants in Food Practical Applications. Eds. Pokorny J, Yanishlieva N \& Gordon M, CRC Press, Woodhead Publ., Cambridge (UK). pp: 210-249. 